\title{
Czy regres publicznego transportu zbiorowego na obszarach górskich prowadzi do rozwoju niezrównoważonego? Przykład z Beskidu Niskiego i Bieszczad
}

\section{Does regression in public transport in naturally-valuable areas lead to unsustainable development? A case study involving Poland's Low Beskids and Bieszczady Mountains}

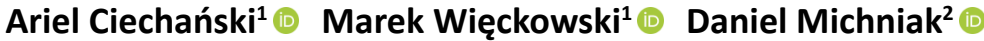 \\ ${ }^{1}$ Instytut Geografii i Przestrzennego Zagospodarowania im. S. Leszczyckiego PAN \\ ul. Twarda 51/55, 00-818 Warszawa \\ ${ }^{2}$ Institute of Geography, Slovak Academy of Sciences \\ Štefánikova 49, 81473 Bratislava \\ ariel@twarda.pan.pl•marekw@twarda.pan.pl•geogmich@savba.sk
}

\begin{abstract}
Zarys treści. Ostatnie ponad 200 lat to okres gwałtownego rozwoju społeczeństw, w tym również i wzrostu ich dobrobytu. Zaowocowało to między innymi rosnącą ilością wolnego czasu, który zwłaszcza bardziej zasobne finansowo jednostki starały się wykorzystać na zaspokojenie potrzeb wyższego rzędu. Skutkiem tego jest przede wszystkim zwiększona mobilność związana z rekreacją i wypoczynkiem. Niestety typowym dla współczesnej cywilizacji jest to, że prawie wszystkie dziedziny gospodarki, w tym transport i turystyka, oddziałują niekorzystnie na środowisko naturalne. Masowy rozwój turystyki i jej negatywny wpływ na otoczenie sprawiają, że rosnące znaczenie mają zasady zrównoważonego rozwoju. Procesom tym powinno towarzyszyć pytanie o granice wzrostu ruchu turystycznego. Ponieważ transport jest integralną częścią sektora turystycznego, brak dogodnych możliwości przemieszczania się owocuje zmniejszaniem się potencjału turystycznego danego obszaru. Transport publiczny jest więc niezbędny na obszarach cennych przyrodniczo jako czynnik sprzyjający zmniejszaniu antropopresji, a zwłaszcza ograniczaniu destruktywnego wpływu motoryzacji indywidualnej.

Bazując na powyższych przesłankach Autorzy podjęli się badań, których celem jest odpowiedź na pytanie: czy regres transportu publicznego na obszarach o dużej wartości środowiska naturalnego, takich Beskid Niski i Bieszczady, prowadzi do niezrównoważonego rozwoju? Latem 2019 r. Autorzy przeprowadzili badanie ankietowe pośród turystów odwiedzających obydwa te pasma górskie i przeanalizowali zmiany sieci transportu publicznego, jakie miały tam miejsce w latach 1990-2019. Na badanym obszarze stale rosnący ruch turystyczny w połączeniu z brakiem wsparcia ze strony organizatorów transportu publicznego prowadzi do pogłębiania się niezrównoważonego rozwoju, a niewystarczająca oferta „przewoźników rozkładowych” nie pozostawia turystom alternatywy dla własnego samochodu i prowadzi do motoryzacji wymuszonej.
\end{abstract}

Słowa kluczowe: transport publiczny, zrównoważony transport, zrównoważona turystyka, wykluczenie transportowe, wymuszona motoryzacja, Polska, Bieszczady, Beskid Niski.

Keywords: public transport, sustainable tourism, sustainable development, transport exclusion, forced motorisation, Poland, Low Beskids, Bieszczady Mts. 


\section{Wstęp}

W obecnych czasach niemal wszystkie dziedziny gospodarki, w tym także transport i turystyka, negatywnie oddziałują na środowisko. W wyniku nadmiernego rozkwitu turystyki oraz jego negatywnego wpływu na środowisko szczególnego znaczenia nabierają zasady zrównoważonego rozwoju, co rodzi wiele pytań, w tym przede wszystkim pytanie o jego granice. Transport jest integralną częścią turystyki i bez jego rozwoju turystyka nie mogłaby funkcjonować. Brak dogodnych możliwości transportowych wpływa na pogorszenie potencjału turystycznego danego obszaru. Dostępność transportowa ma znaczenie zarówno w dotarciu do obszaru turystycznego, jak też warunkuje poruszanie się po nim. Transport publiczny ma szczególne znaczenie w obszarach cennych przyrodniczo. Jego brak, słabe funkcjonowanie, wysoka cena lub niska jakość prowadzić mogą do zaburzeń rozwoju turystyki i innych działów gospodarki, jak też niszczenia środowiska przyrodniczego (Michniak i Więckowski, 2021).

Do najcenniejszych przyrodniczo obszarów Polski zalicza się m.in. góry. Ze względu na atrakcyjny krajobraz oraz warunki do uprawiania wielu rodzajów turystyki stanowią obszar zainteresowania turystów oraz rozwoju całego sektora turystycznego. Jego funkcjonowanie zależy od wielu czynników: przyrodniczych, ekonomicznych i społecznych. Część z nich ma duże znaczenie dla zrównoważonego jej funkcjonowania, gdyż wykorzystanie zasobów odbywa się kosztem środowiska przyrodniczego lub społeczno-kulturowego (Zawilińska i Szpara, 2016; Ćwik i Hrehorowicz-Gaber, 2021). Tym samym pojawia się potrzeba dyskusji i krytycznej oceny zarządzania, polityki, planowania, marketingu, mobilności ludzi, które mają związek z branżą turystyczną (Więckowski i Saarinen, 2019). Jej rozwój wymaga lepszego zrozumienia funkcjonowania transportu jako istotnej składowej osiągnięcia zrównoważonego rozwoju w dalszej przyszłości (Ciechański, 2020) i prowadzenia badań w różnych skalach przestrzennych: regionalnej i lokalnej (w szczególności takie, które nie bazują tylko na ogólnodostępnych danych statystycznych). W Polsce brakuje badań dotyczących związków turystyki, zmian sieci transportowej i rozwoju zrównoważonego. Celem niniejszego badania prowadzonego w ramach szerszego projektu dotyczącego problematyki wykluczenia transportowego w Beskidzie Niskim i Bieszczadach ${ }^{1}$ było rozpoznanie skali zmian sieci publicznego transportu zbiorowego między latami 1990 a 2019 oraz ich wpływu na postawy transportowe turystów odwiedzających te pasma górskie. Autorzy artykułu ponadto zakładają, że przy stale rosnącym ruchu turystycznym na badanym obszarze, brak wsparcia ze strony organizatorów transportu publicznego będzie prowadził do pogłębiającego się rozwoju niezrównoważonego. Przyjmują też założenie, że w turystyce możemy mówić o odpowiedniku wymuszonej motoryzacji - czyli sytuacji, w której turyści przez słabą ofertę transportu publicznego zostają niejako zmuszeni do przemieszczania się samochodem.

${ }^{1}$ Artykuł powstał częściowo na podstawie badań w ramach realizacji projektu badawczego sfinansowanego przez NCN pt. Empiryczne badania pilotażowe dotyczqce problematyki wykluczenia transportowego na obszarach górskich na przykładzie powiatów Beskidu Niskiego i Bieszczad (Miniatura 2, nr umowy 2018/02/X/ HS4/00451) i w ramach realizacji projektu VEGA 2/0019/21. 


\section{Zrównoważona turystyka i transport - wzajemne relacje}

Zrównoważony rozwój ma trzy główne aspekty: środowiskowy, gospodarczy i społeczny. Ważne jest znalezienie równowagi między wszystkimi trzema wymiarami. W niniejszym artykule proponujemy dyskusję o relacjach między turystyką i transportem w zakresie rozwoju zrównoważonego, ze szczególnym uwzględnieniem obszarów cennych przyrodniczo.

\section{Zrównoważona turystyka}

Zrównoważoną turystykę należy traktować jako nowy sposób myślenia i poznawania świata. Można ją zdefiniować jako formę podróżowania, która w pełni uwzględnia jej obecny i przyszły wpływ gospodarczy, społeczny i środowiskowy na obszar turystyczny, zaspokajając potrzeby odwiedzających, przemysłu, środowiska i społeczności przyjmujących (UNEP, 2005). Turystyka może często powodować szkody w środowisku, powodując zagrożenia takie jak erozja gleb, zanieczyszczenie powietrza, wody, roślinności czy gleby, utrata siedlisk przyrodniczych i pożary lasów. Wytyczne dotyczące zrównoważonego rozwoju turystyki i praktyki zarządzania mają zastosowanie do wszystkich jej form we wszystkich typach miejsc, w tym do turystyki masowej i różnych segmentów turystyki niszowej. Zasady zrównoważonego rozwoju odnoszą się do środowiskowych, ekonomicznych i społeczno-kulturowych aspektów rozwoju turystyki i należy zapewnić odpowiednią równowagę między tymi trzema wymiarami, aby zagwarantować jego długoterminową trwałość.

\section{Zrównoważony transport}

Bez względu na szczegółową definicję zrównoważonego transportu często pojawia się odniesienie do „potrójnej dolnej linii” zrównoważonego rozwoju pod względem ekonomicznym, środowiskowym i społecznym. Jednakże zdefiniowanie wskaźników zrównoważonego rozwoju transportu jest bardzo zróżnicowane (Richardson, 2005). Zazwyczaj zrównoważony transport definiuje się w odniesieniu do emisji i zużycia energii (Himanena et al., 2005). Koncepcja „zrównoważonej mobilności” pojawiła się jako część międzynarodowej agendy (EC, 2002). W literaturze terminy „zrównoważony transport” (także „zrównoważone systemy transportowe” itp.) oraz „zrównoważona mobilność” są używane synonimicznie (Holden, 2007). Wydaje się, że pojęcie zrównoważonego transportu jest preferowane w Ameryce Północnej, a zrównoważonej mobilności - w Europie (Black, 2003).

\section{Transport i turystyka}

Transport jest integralną częścią działalności w sektorze turystyki i wraz z produktem turystycznym (lub podażą) i rynkiem turystycznym (lub popytem), jest jednym z trzech podstawowych elementów turystyki. Rola transportu w turystyce jest znacząca i podkreślana przez wielu autorów; jest składnikiem teorii i koncepcji turystyki oraz produktu turystycznego (Cardenas Tabares, 1998; Prideaux, 2000; Taylor, 2018). Modernizacja infrastruktury transportowej zwiększa atrakcyjność miejsc turystycznych i pomaga w odkrywaniu nowych miejsc. Z kolei wzrost ruchu turystycznego zmusza decydentów do poprawy systemów transportu. Z drugiej strony słaba dostępność powoduje, że turyści uciekają 
do regionów o lepszej dostępności, rozwoju i organizacji oraz lepszej jakości usług. Słaba dostępność może być też przyczyną upadku regionu turystycznego (Sorupia, 2005).

Klasyczne związki transportu z turystyką, które jednocześnie można rozpatrywać z punktu widzenia zrównoważonego rozwoju, dotyczą trzech przestrzennych typów relacji: dojazdu do obszaru; przemieszczanie się po obszarze turystycznym oraz transport w multidestynacyjnych podróżach (Więckowski, 2021). Z punktu widzenia niniejszego artykułu najważniejszy jest aspekt dojazdu do obszaru i przemieszczania się w obrębie destynacji turystycznej.

Dojazd do obszaru. Zarówno środki transportu, jak i infrastruktura znajdują się poza obszarem destynacji. Mogą nie być w całości, względnie w większości projektowane i/lub wykorzystywane do celów turystycznych (samoloty lub autobusy rejsowe, sieć drogowa, sieć kolejowa) (Taylor, 2018). Obszar turystyczny może więc nie mieć większego wpływu na możliwości dotarcia do niego, gdyż zależą one od działań aktorów zewnętrznych. Jednakże na poziomie kraju taki wpływ może być większy, gdy szczególnie infrastruktura, ale też środki transportu (a w konsekwencji kwestie dostępności) zaczną być przedmiotem mądrego i logicznego kształtowania planistycznego (Więckowski, 2021).

Transport w destynacji turystycznej daje możliwości poruszania się po obszarze (w czym ma znaczenie: rodzaj transportu, istniejąca sieć i organizacja ruchu) oraz dostępu do atrakcji turystycznych (Więckowski, 2021). Są to zarówno możliwości dotarcia do atrakcji (z miejsc zamieszkania w destynacji turystycznej) za pomocą transportu kolejowego lub drogowego, jak też inne środki pozwalające na przemieszczanie się po obszarze. Szczególnego znaczenia w zrównoważonym rozwoju nabiera transport zbiorowy (publiczny), który generalnie jest lepiej rozwinięty w obszarach zurbanizowanych (Le-Klähn et al., 2014; LeKlähn i Hall, 2015), natomiast zdecydowanie słabiej w oddalonych obszarach wiejskich, takich jak na przykład parki narodowe, obszary i ośrodki górskie (Lumsdon, 2006; Guiver et al, 2007; Imhof et al., 2009).

\section{Transport publiczny a turystyka}

Literatura dotycząca pozamiejskiego transportu zbiorowego jest niewątpliwie różnorodna. Głównym obszarem zainteresowania badaczy są zmiany sieci połączeń kolejowych. Na drugim biegunie są znacznie skromniejsze badania z zakresu ewolucji sieci pozamiejskiego transportu autobusowego, które nigdy nie cieszyły się większym zainteresowaniem geografów czy też przedstawicieli innych dyscyplin naukowych i mają charakter przede wszystkim statyczny.

Badania dotyczące zmian sieci kolejowych połączeń pasażerskich zapoczątkowane zostały jeszcze w dwudziestoleciu międzywojennym i miały klasyczny, czysto dokumentacyjny charakter (np. Bissaga, 1938). Ten nurt badawczy utrzymał się po 1945 r. i niewątpliwy kanon wyznaczyła tu pionierska praca Lijewskiego (1959) kompleksowo ustalająca daty powstawania poszczególnych odcinków linii kolejowych na obecnym terytorium Polski. Jej kontynuację stanowią liczne pozycje porządkujące momenty otwierania bądź zamykania odcinków sieci kolejowej - szczególnie znaczący dorobek posiada Koziarski $(1985,1989$, 1990, 1993a, 1993b; Lijewski i Koziarski 1995). W ostatnich latach tego typu badania prowadzili zarówno doświadczeni badacze (Taylor, 2007), jak również młodzi naukowcy w ramach prac na stopień - (Bagińska, 2007; Komusiński, 2010; Ciechański, 2013). 
W przypadku pozamiejskiego transportu autobusowego brakuje opracowań chronologicznie ukazujących w różnych skalach przestrzennych rozwój i regres sieci połączeń. Niestety nawet w okresie PRL, choć dostęp do rozkładów jazdy był o wiele łatwiejszy, nikt nie pokusił się o opracowanie chronologii zmian w sieci połączeń autobusowych w Polsce. W pracy Lijewskiego et al. (1967) podjęto problematykę przewozów autobusowych w skali kraju w formie bardzo syntetycznej i w ujęciu statycznym. Z kolei w pracy Kozaneckiej (1980) szczególnie cenne, z punktu widzenia opisywanych badań, są załączone do niej kartodiagramy wstęgowe utrwalające obraz pozamiejskiego transportu autobusowego w kilku przekrojach czasowych.

Częściej powstawały prace o zasięgu regionalnym bądź lokalnym i niestety wyłącznie w ujęciu statycznym. W tym pierwszym nurcie mieści się monografia komunikacji w województwie białostockim autorstwa Lijewskiego (1962). Podobnie należy rozpatrywać artykuł Stawickiego (2014), który dokumentuje liczbę połączeń ośrodków Mazowsza z Warszawą w 2014 r. (poza obszarem obowiązywania biletów ZTM). Dej (2010) schodzi do skali wręcz lokalnej. W tej samej skali porusza się Kretowicz (2010), skupiając się na rosnącej substytucji połączeń realizowanych dotąd przez przewoźników państwowych. Autor ten zauważył, że proces wycofywania się z połączeń lokalnych do miejscowości peryferyjnych w powiecie gorlickim rozpoczął się już w latach 90., a PKS-y pozostawały jedynym przewoźnikiem tylko na słabo zaludnionych obszarach. Guzik z zespołem (Guzik et al., 2016) dla Miejskiego Obszaru Funkcjonalnego (MOF) Olsztyna, a także Kretowicz (2010) dla południowej Małopolski zauważają, że miejscowości wiejskie, do których prowadzi niskiej jakości infrastruktura drogowa i które zamieszkuje niewielka liczba osób, mają bardzo słabą dostępność za pomocą transportu publicznego. Autorzy ci podkreślają, że brak wsparcia transportu publicznego skutkuje ograniczeniem dostępu do miejsc pracy i edukacji, co później może prowadzić do wydatkowania znacznych kwot na zasiłki i pomoc społeczną. Guzik i Kołoś (2015) podobne obserwacje poczynili dla województwa pomorskiego, gdzie 18\% przebadanych sołectw było odciętych całkowicie od transportu publicznego (do kilkudziesięciu z nich nie prowadziły drogi o nawierzchni bitumicznej), a tylko w latach 2011-2014 na tym obszarze badawczym aż 172 miejscowości utraciło do niego dostęp. Analiza dla dziewięciu MOF, jaką w tym zakresie przeprowadził Wolański et al. (2016), nie skłania do optymizmu - brakuje interwencji na obszarach, gdzie zaprzestano obsługi transportowej, a większość organów niestety ogranicza się w dziedzinie transportu tylko do funkcji czysto administracyjnych (w tym organizacji kursów szkolnych) oraz do poboru podatków i opłat. W tym samym nurcie porusza się ostatnio Beim et al. (2019), dokonując diagnozy nienapawającego optymizmem stanu transportu publicznego w podregionie pilskim.

Rzadko badacze podejmują tą problematykę w ujęciu dynamicznym - tu warto przytoczyć pracę Chodkowskiej-Miszczuk (2006). Porównując interesujące kartodiagramy dla sieci transportu publicznego w pięciu wybranych aglomeracjach dla 1985, 1995 i 2005 r. już wtedy zauważyła ona nasilenie procesów polaryzacji przewozów autobusowych (znaczny spadek liczby połączeń na odcinkach peryferyjnych). Podobne do badań Beima, ale w ujęciu bardziej dynamicznym i dla większego obszaru (powiatów Beskidu Niskiego i Bieszczad), przeprowadził Ciechański (2020). Na tym tle szczególnie istotne jest praca Kołodziejczyka (2017), w której analizuje on dawną i współczesną siatkę połączeń kolejowych i autobusowych na terenie ziemi kłodzkiej oraz łączących ją z pozostałymi częściami kraju. Podobne wnioski wykazują Kołodziejczyk (2020) oraz Więckowski (2004) 
badając transport puliczny (zarówno połączenia kolejowe jak też autobusowe) w ujęciu transgranicznym. Zauważają oni te same procesy, które obserwują autorzy niniejszego artykułu dla Beskidu Niskiego i Bieszczad. Także w Sudetach Wschodnich i Kotlinie Kłodzkiej wiele atrakcji i obszarów interesujących z turystycznego punktu widzenia pozostaje niedostępnych dla osób niezmotoryzowanych. Również i tutaj istniejąca oferta nie zachęca turystów zmotoryzowanych do rezygnacji z samochodu na rzecz publicznego transportu zbiorowego.

\section{Obszar badań}

Niniejsze badania obejmują obszar Beskidu Niskiego oraz Bieszczad położonych w Karpatach, południowo-wschodniej części Polski. Karpaty mają niezwykle bogate zasoby krajobrazowe i bioróżnorodności (Buza i Turnock, 2004; Zawilińska, 2010). Górzysta rzeźba i obszary chronionej przyrody stanowiły barierę dla transportu i turystyki, ale z drugiej strony górzysty obszar stanowi bardzo dobre warunki do rozwoju turystyki (Warszyńska, 1985; Groch i Kurek, 1995; Ptaszycka-Jackowska i Baranowska-Janota, 2003; Więckowski, 2004, 2020; Faracik et. 2009, Zawilińska, 2010 oraz Więckowski et al., 2012). Turystyka od wielu dziesięcioleci jest uważana za ważną gałąź gospodarki w Karpatach, a także często traktowana jako jedyna szansa rozwoju społeczno-gospodarczego. Dwie dodatkowe, tradycyjne gałęzie gospodarki w tym regionie to rolnictwo i leśnictwo (Jabs i Affek, 2019). Góry wpływają na rozwój specyficznych rodzajów turystyki w Karpatach. Formy współczesnej turystyki na tych terenach to przede wszystkim różnorodne formy turystyki przyrodniczej, wypoczynkowej, przygodowej, leczniczej, tranzytowej, kulturalnej, gastronomicznej i wydarzeń (Więckowski, 2020).

Zmiany polityczne i gospodarcze po 1989 r. przyczyniły się do rozwoju transportu transgranicznego i turystyki po obu stronach granicy. Budowa nowych dróg transgranicznych umożliwiła rozwój bardziej intensywnych kontaktów mieszkańców i rozwój turystyki transgranicznej (Michniak et al., 2015).

\section{Metody}

Empiryczna część badań bazowała na ankietach oraz wykorzystaniu danych statystycznych do kartograficznego przedstawienia zjawiska. W trakcie badania powstała baza rozkładów publicznego transportu zbiorowego z aktualnością na początek 2019 r. Posłużyła ona do opracowania map pokazujących z jednej strony liczbę połączeń w przeciętny dzień roboczy, z drugiej zaś linie obsługiwane tylko w dni robocze bądź też tylko w dni nauki szkolnej. Pominięte zostały wszelkie kursy zamknięte jak dowozy organizowane przez szkoły czy też pracodawców, których rozkład nie jest podawany do wiadomości publicznej. Na mapach zaznaczono także odcinki, które były obsługiwane w 1990 r., a obecnie pozostają bez publicznego transportu zbiorowego.

Odrębne zagadnienie stanowi utrudniony dostęp do informacji o rozkładach jazdy transportu autobusowego. Można odnieść wrażenie, że od lat ten problem się nawarstwia. Nadal w Polsce brakuje łatwego dostępu do kompletnych i rzetelnych danych pierwotnych (Guzik et al., 2016). Pogłębia ten problem ogromne rozproszenie i utrudniony 
dostęp do rozkładów jazdy autobusów, a także pełna dowolność form, w jakich są one przechowywane (Rosik et al., 2017). Co zaskakujące, wciąż wielu przewoźników nie posiadało własnych stron internetowych, a integracja danych o rozkładach odbywała się $\mathrm{np}$. za pomocą prowadzonych hobbystycznie lokalnych portali (Wolański et al., 2016). Ciechański (2019) podkreśla, że dla sporej grupy przewoźników autobusowych poza obszarem ich działania wciąż brak jest wiarygodnych i łatwo dostępnych źródeł wiedzy o ich rozkładzie, a zdobycie informacji o pełnej siatce połączeń nadal jest bardzo czasochłonne oraz kosztochłonne.

W trakcie badania przeprowadzonego w 2019 r. zapytano turystów o wpływ sytuacji transportowej na wybór środków przemieszczania się. Wybrano metodę ankiety bezpośredniej w formie kwestionariusza oddawanego zaraz po wypełnieniu. Przyjęto próbę celową, to jest osoby uprawiające aktywną turystykę, dlatego też dystrybucję formularzy prowadzono w obiektach studenckiej bazy noclegowej, schroniskach turystycznych oraz w punktach węzłowych na szlakach turystycznych. Badania na obszarze Bieszczad przeprowadzono w dwóch przekrojach czasowych - w sezonie średnim (połowa czerwca nieobejmująca długiego weekendu) i w sezonie wysokim (okres wakacyjny) (tab. 1). Przed wakacjami badania prowadzano wyłącznie na obszarze Bieszczadzkiego Parku Narodowego. W sezonie wakacyjnym część ankiet zrealizowano także w mniej uczęszczanej zachodniej części pasma. Dla Beskidu Niskiego, ze względu na specyfikę ruchu (większość schronisk czy baz studenckich działa tylko w wakacje), badanie prowadzono jedynie w okresie wakacyjnym - głównie w tzw. Beskidzie Dukielskim, w mniejszym stopniu w tzw. Beskidzie Gorlickim.

Tabela 1. Charakterystyka badania ankietowego

Characteristics of the survey

\begin{tabular}{|l|c|c|c|c|}
\hline \multicolumn{1}{|c|}{ Obszar badania } & \multicolumn{2}{|c|}{ Bieszczady } & $\begin{array}{c}\text { Beskid Niski } \\
\text { (Dukielski) }\end{array}$ & $\begin{array}{c}\text { Beskid Niski } \\
\text { (Gorlicki) }\end{array}$ \\
\hline Daty badania & $10-14.06 .2019$ & $\begin{array}{l}24-29.07 .2019 \\
19-22.08 .2019\end{array}$ & $\begin{array}{c}\text { 02.07-08.07.2019 } \\
05-08.08 .2019\end{array}$ & $26-28.08 .2019$ \\
\hline Zrealizowana liczba ankiet & 75 & 157 & \multicolumn{2}{|c|}{52} \\
\hline
\end{tabular}

\section{Transport na badanym obszarze w 2019 r.}

\section{Infrastruktura transportowa}

Sieć linii kolejowych w przedmiotowym obszarze ukształtowała się w ostatnich 30 latach XIX w. i tworzą ją obecnie normalnotorowe jednotorowe odcinki o charakterze drugorzędnym: (Medzilaborce)-Łupków-Zagórz-Krościenko-(Chyrów), Stróże-Jasło-Zagórz, Zagórzany-Gorlice oraz Jasło-Rzeszów (Koziarski i Lijewski, 1995).

Główną oś w transporcie samochodowym obszaru badawczego, a zarazem jego północną granicę, stanowi droga krajowa (DK) nr 28 na odcinku Ropa-Gorlice-Jasło-KrosnoSanok. Taki sam charakter od Sanoka do granicy państwa w Krościenku ma DK84. Istotnym ciągiem transportowym, przebiegającym na odcinku Krosno-Dukla-Granica Państwa przez teren obszaru badawczego, jest DK19. Pozostałe drogi zaliczają się do kategorii dróg wojewódzkich (DW), powiatowych i gminnych.

Dostępność transportowa w ujęciu transgranicznym jest najlepsza na krańcach obszaru: na zachodzie, gdzie przebiega korytarz drogowy DK19 przez Przełęcz Dukielską Barwi- 
nek-Vyšný Komárnik oraz na wschodzie, gdzie istnieje relatywnie dobra droga powiatowa prowadząca do przejścia granicznego Radoszyce-Palota. Na granicy obszaru biegnie również linia kolejowa przecinająca granicę polsko-słowacką z Nowego Zagórza do Łupkowa i miejscowości Medzilaborce; jest w złym stanie technicznym, a jednocześnie ma duży potencjał turystyczny, w znacznej mierze niewykorzystany (Więckowski et al., 2012).

\section{Sieć połączeń transportu publicznego}

Geograficzna i gospodarcza peryferyjność jest widoczna także w stanie infrastruktury transportowej. Nie wszystkie polskie regiony w Karpatach stały się beneficjentami pełnego rozwoju turystyki, zwłaszcza w aspekcie transportu publicznego. Z jednej strony jest to skutkiem warunków fizycznogeograficznych i zaszłości historycznych w kształtowaniu się sieci kolejowej, z drugiej jednak wpływają na to czynniki całkowicie współczesne. We wschodniej części pogranicza (Beskid Niski i Bieszczady) sytuacja wygląda dość dramatycznie (Więckowski et al., 2012; Ciechański, 2020). Po stronie polskiej krajowy transport kolejowy został całkowicie zmarginalizowany. Jakość i ilość połączeń pozamiejskim publicznym transportem autobusowym jest znacznie poniżej europejskich standardów. Szczególnie zyskujące jest to w przypadku Bieszczad, gdzie poza sezonem turystycznym transport zbiorowy praktycznie nie istnieje, a w wakacje jego rolę pełnią funkcjonujące poza wszelkim systemem busy (Ciechański, 2019). Obsługa wschodniej części pogranicza transportem publicznym po stronie słowackiej jest lepsza, ponieważ większość miejscowości ma połączenie autobusowe organizowany przez samorząd regionalny, choć polaczenia nie zawsze są wystarczające (Székely i Novotný, 2019).

Duża część dróg na słabo dostępnym obszarze Bieszczadów została w ostatnich latach zmodernizowana, co znacznie zwiększyło wygodę podróżowania. Warto podkreślić, że powiat bieszczadzki charakteryzuje najmniejsza gęstość dróg powiatowych i gminnych w Polsce, co wiąże się z jednej strony z małą gęstością zaludnienia, a z drugiej strony z ukształtowaniem powierzchni terenu. Jedyną linią kolejową w polskiej części badanego regionu jest wąskotorowa Bieszczadzka Kolei Leśna wykorzystywana w celach turystycznych (w sezonie letnim) na trasie Balnica-Przysłup-Cisna-Majdan.

W 2019 r. rola transportu kolejowego na opisywanym obszarze była marginalna (ryc. 1). Na linii z Zagórza do Krościenka i dalej do Chyrowa z powodu złego stanu toru przewozy były wstrzymane, a na odcinku Stróże-Gorlice Zagórzany-Jasło (wraz z odgałęzieniem do Gorlic) okresowo realizowano jedynie nieliczne kursy weekendowe. Na pozostałych odcinkach ruch pociągów spółki Przewozy Regionalne był na granicy minimalnej uzasadnionej ekonomicznie oferty (Rzeszów-Jasło, siedem par pociągów) lub wręcz poniżej jej (Jasło-Sanok - cztery pary, Sanok-Zagórz - pięć par, Zagórz-Komańcza - trzy pary). W dni wolne od pracy liczby te były zazwyczaj jeszcze niższe (wyjątek stanowiła linia do Łupkowa z wakacyjnymi dodatkowymi pociągami do słowackich Medzilaborców) (Ciechański, 2020). Łączność z resztą kraju zapewniały pociągi pospieszne PKP Intercity (skomunikowane w Rzeszowie lub Sędziszowie Małopolskim z pociągami w kierunku Warszawy i Gdyni).

Należy zaznaczyć, że Krosno, Sanok i Jasło oraz Lesko (od września 2019) miały bezpośrednie połączenia z Rzeszowem busami firmy Marcel. W ruchu dalekobieżnym do Sanoka (z pojedynczymi kursami także bezpośrednio w Bieszczady) oraz do uzdrowisk Beskidu Niskiego liderem był Neobus. Kilku przewoźników wykonywało kursy z Gorlic, Ustrzyk 


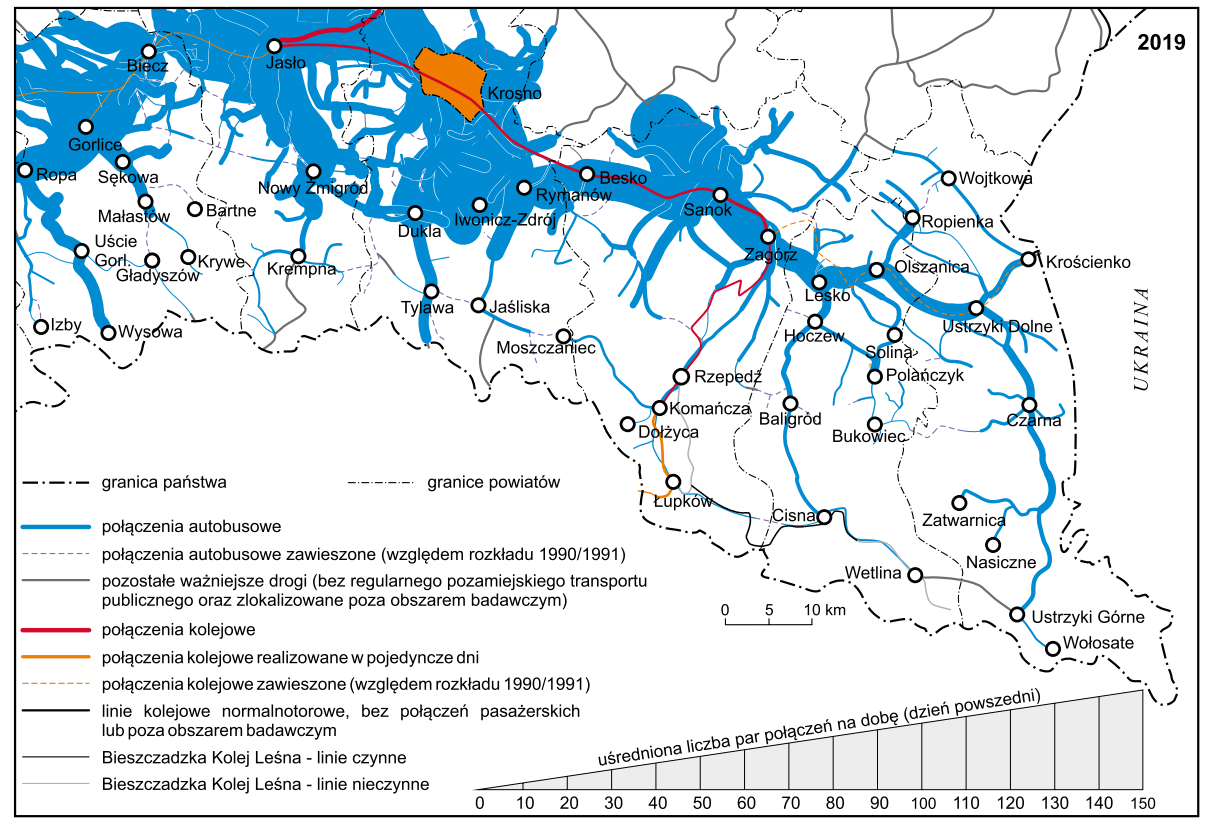

Ryc. 1. Sieć pasażerskiego pozamiejskiego transportu publicznego na obszarze Beskidu Niskiego i Bieszczad w 2019 r.

The network of passenger transport in the area of the Low Beskids and Bieszczady Mountains as of 2019 Źródło: Ciechański (2020).

Dolnych oraz Bieszczad w kierunku Krakowa. Pojawiły się też sezonowe kursy Flixbusa z Ustrzyk Dolnych do Poznania.

Rynek lokalnych przewozów autobusowych był znacznie bardziej zróżnicowany, aczkolwiek o charakterze zbliżonym do lokalnych oligopoli (Ciechański, 2020). W 2019 r. najlepszą ofertą lokalnych przewoźników autobusowych niewątpliwie charakteryzował się ciąg DK28. Na dobrym poziomie utrzymywała się również obsługa Dukli, Nowego Żmigrodu i Wysowej. Południowe, górskie i gorzej zaludnione części powiatów w większości cechowały się jednak znacznie gorszą ofertą przewozową. O ile jeszcze w połączeniach poprowadzonych głównymi dolinami sytuacja była w miarę optymistyczna, to w przypadku relacji biegnących wzdłuż pasm górskich (z punktu widzenia turysty najistotniejszych) było znacznie gorzej. W Beskidzie Niskim przestały funkcjonować istniejące w 1990 r., relacje Gorlice-Nowy Żmigród, Małastów-Gładyszów, Krempna-Dukla, Wola Niżna-Moszczaniec, Wola Michowa-Żubracze oraz Tylawa-Jaśliska. W Bieszczadach dostrzegalny był natomiast kryzys wywołany stopniowym upadkiem, a następnie likwidacją w czerwcu 2017 r. oddziałów firmy Arriva Bus Transport Polska w Sanoku i Ustrzykach Dolnych. To między innymi uniemożliwiło przejazd z okolic Bukowca do Czarnej, zaś pozostała obsługa rejonu Jeziora Solińskiego, a w szczególności Bukowca (ryc. 1), ukształtowała się na wyjątkowo słabym poziomie. Bardzo mało autobusów docierało poza sezonem turystycznym do Cisnej i Wetliny, a także na południe od Komańczy. W Beskidzie Niskim to samo dotyczyło głównie gminy Uście Gorlickie i Sękowa, a także częściowo gminy Dukla oraz południowych rubieży gminy Rymanów. 
Dla turystów jednak najbardziej istotne były połączenia wykonywane w dni wolne od nauki i pracy (ryc. 2). Niestety na większości linii w soboty kursowało znacznie mniej busów, a w niedziele i święta na wiele linii wyjeżdżały tylko pojedyncze kursy lub też nie były one w ogóle obsługiwane (np. Krosno-Dukla w dni robocze - blisko 70 kursów, w soboty - kilkanaście, w niedziele - cztery kursy, a w niektóre dni świąteczne - zero). Nawet dwa miasta powiatowe Krosno i Jasło w niedzielę łączyły tylko autobusy pospieszne i nieliczne pociągi. Ponadto przez weekendy bez dostępu do transportu publicznego pozostawał rejon zbiornika solińskiego oraz niemal wszystkie górskie miejscowości w gminach Czarna, Lutowiska oraz Komańcza (tu wieś gminna była również „odcięta od świata”, gdyby nie 1-3 połączenia kolejowe na dobę). Na obszarze Beskidu Niskiego identyczna sytuacja dotyczyła praktycznie całej gminy Jaśliska i niemal całej Uście Gorlickie, a także południa gminy Rymanów oraz położonych w bocznych dolinach górskich wsi gmin: Dukla, Krempna i Sękowa. W okresie wakacyjnym paradoksalnie większość z wspomnianych powyżej dość popularnych wśród turystów obszarów była całkowicie pozbawiona rozkładowego transportu publicznego (m.in. były to: Nasiczne, Zatwarnica, Polany, Michniowiec, Chrewt, Wisłoczek, Krywe i Bartne).

Powyższa sytuacja transportowa nie sprzyja rozwojowi zrównoważonemu - turyści nie mają alternatywy dla przyjazdu i przemieszczania się w górach w sposób najmniej ekologiczny czyli za pomocą swojego prywatnego samochodu.

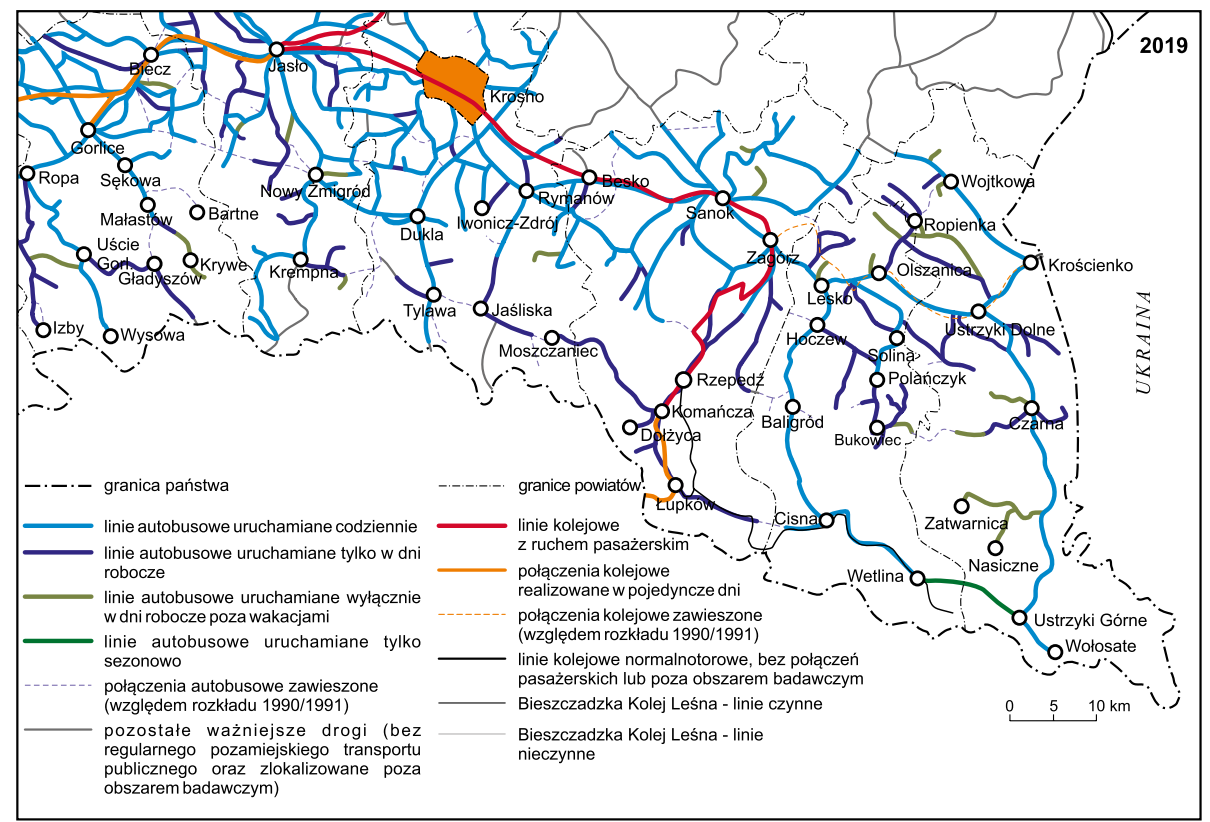

Ryc. 2. Sieć pasażerskiego transportu na obszarze Beskidu Niskiego i Bieszczad w 2019 r. w podziale na linie obsługiwane codziennie, tylko $w$ dni robocze i wyłącznie w dni nauki szkolnej

The network of passenger transport in the area of the Low Beskids and Bieszczady Mountains in 2019, with a division into lines operated every day, on working days only and on school days only Źródło: Ciechański (2020). 


\section{Wyniki badań - motoryzacja wymuszona w turystyce jako krok ku rozwojowi niezrównoważonemu}

Przystępując do badania ankietowego dotyczącego problemów transportowych turystów w Bieszczadach i Beskidzie Niskim autorzy zakładali, że zwłaszcza poza okresem wakacyjnym turyści są zmuszeni do korzystania z własnego środka transportu, a ponadto, że występuje tu zróżnicowanie sezonowe podziału modalnego. Takie założenie wynikało to z tego, że oferta transportu publicznego od września do czerwca jest bardziej ograniczona, a oferta jeżdżących bez rozkładu jazdy i biletów prywatnych busów utrudnia zaplanowanie wędrówek górskich.

W ankiecie respondenci byli pytani, czy ze względu na brak dogodnego dojazdu transportem zbiorowym decydowali się na wykorzystanie własnego pojazdu. Widoczna jest tu znaczna różnica pomiędzy poza sezonem głównym, gdzie w przypadku Bieszczad aż 26,7\% respondentów z tego względu zdecydowała się na poruszanie się własnym pojazdem (zazwyczaj autem). Tymczasem w sezonie letnim w tych samych Bieszczadach na taki krok zdecydowało się 17,8\% badanych, a w przypadku Beskidu Niskiego 15,4\% badanych.

W tym miejscu należy się przyjrzeć, jak dojazdy w góry wyglądały od strony podziału modalnego (ryc. 3). W dojazdach w Bieszczady kolej jako samodzielny środek transportu nie ma niemal żadnego znaczenia, co nie jest zaskakujące, biorąc pod uwagę oferty przewoźników i czas przejazdu. Nieco częściej kolej występuje w połączeniu z transportem autobusowym. Nie mamy jednak odpowiedzi, czy respondenci docierali (jak dawniej) do Sanoka/Zagórza, czy jednak „kolejowymi drzwiami Bieszczad” nie stał się obecnie węzeł w Rzeszowie. Obserwowane jest większe znaczenie transportu autobusowego, ale, co zaskakuje, nie różni się ono znacznie w przypadku Bieszczad pomiędzy czerwcem, a miesiącami wakacyjnymi. Nie mniej jednak w obydwu przypadkach wśród respondentów dominowali użytkownicy samochodów prywatnych (odpowiednio ponad 82\% i 72\%). Zupełnie inną charakterystykę posiada tu wakacyjny Beskid Niski, gdzie ponad 45\% użytkowników w dojeździe w góry wykorzystywało transport publiczny. Trudno jednak jest wy-
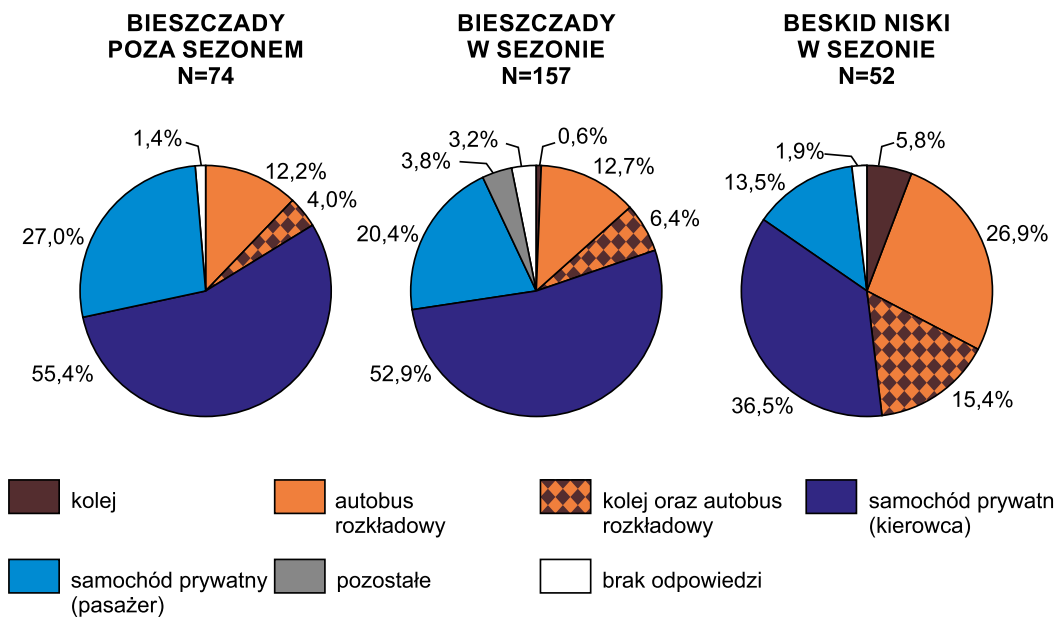
(pasażer)

Ryc. 3. Środki transportu wykorzystywane w dojeździe w góry

Means of transport used to access the mountains 
rokować na podstawie samego odsetka odpowiedzi, na ile jest to skutkiem lepszej oferty transportu publicznego, a na ile specyfiki ruchu turystycznego w tym paśmie i tym samym ankietowanych respondentów.

W przypadku oceny dojazdu transportem publicznym w Beskid Niski jego użytkownicy byli raczej krytyczni, natomiast dla Bieszczad odpowiedzi były zróżnicowane (gorsza ocena poza sezonem) (ryc. 4).
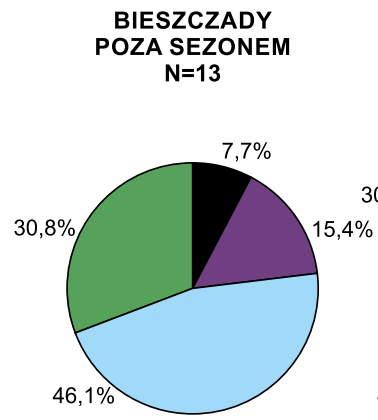

bardzo źle
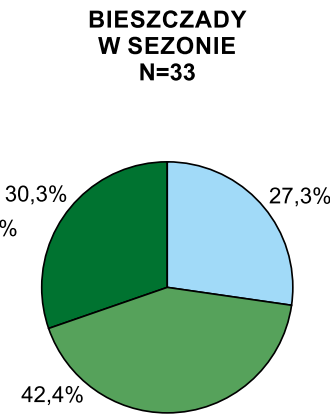

dostatecznie
BESKID NISKI

W SEZONIE

$\mathrm{N}=22$

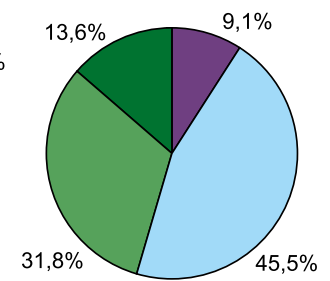

dobrze

bardzo dobrze

Ryc. 4. Ocena jakości publicznego transportu zbiorowego w dojeździe w góry

Assessment of the quality of collective public transport in travelling to the mountains

Turystów pytano również o przyczyny niekorzystania z transportu publicznego. Przede wszystkim respondenci bardzo cenili sobie swobodę, jaką daje wykorzystanie prywatnego samochodu (ryc. 5). Kolejną istotną odpowiedzią był niekonkurencyjny czas przejazdu, który w przypadku transportu publicznego z przesiadką może być nawet dwukrotnie dłuższy (ale np. bezpośrednie autobusy firmy Neobus jadące z Ustrzyk Górnych do Warszawy miały zwłaszcza nocą porównywalny czas przejazdu). Z drugiej jednak strony, o ile zapewniały doskonały powrót nocą wprost ze szlaku do domu, to w przypadku dojazdu w Bieszczady docierały w nie późnym popołudniem. Trzecim czynnikiem skłaniającym turystów do przyjazdu w góry autem jest brak transportu publicznego (lub też wiedzy o jego istnieniu) w docelowej miejscowości. Także nadmierna liczba przesiadek odstręczała użytkowników od wykorzystania transportu publicznego. Do przemieszczania się własnym pojazdem skłaniała też słaba siatka połączeń transportu publicznego na docelowym obszarze i konieczność zabrania większego bagażu (często podkreślana w bezpośrednich rozmowach respondentów z prowadzącym badanie). Cena przejazdu czy jakość pojazdów nie odgrywały tu ważnej roli.

Bardziej interesujące wnioski wypływają niewątpliwie z danych dotyczących przejazdów w trakcie pobytu w górach (ryc. 6). W Bieszczadach ze względu na peryferyjny przebieg linii kolejowej względem najatrakcyjniejszego pasma połonin, rola tego środka transportu jest marginalna. Niemal identycznie sytuacja przedstawia się dla Beskidu Niskiego, gdzie linia kolejowa przebiega równolegle do tego łańcucha górskiego, ale jednak w sporym oddaleniu od niego. Poza sezonem wakacyjnym w Bieszczadach najpopularniejszym środkiem transportu był prywatny samochód wskazywany przez ponad połowę 


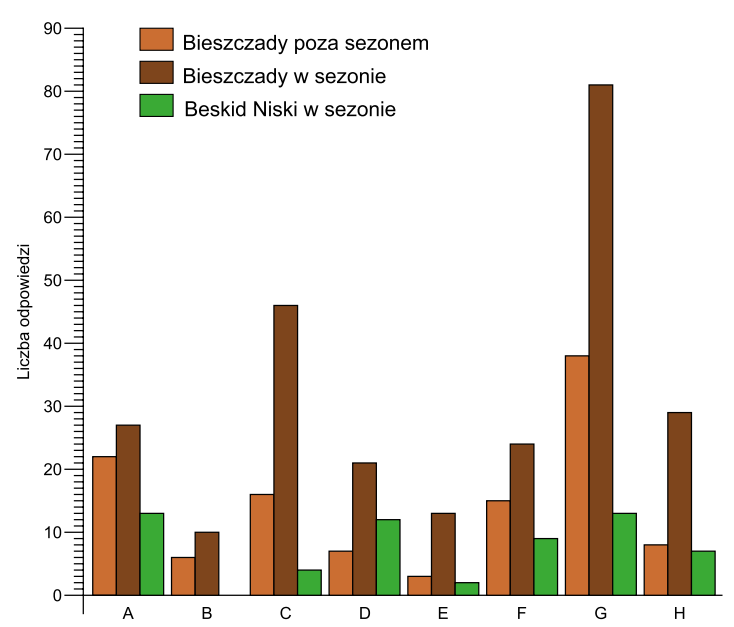
A-brak takiego środka transportu obsługującego docelową miejscowość
B-zbyt wysokie ceny biletów
C-niekonkurecyjny (zbyt długi) czas dojazdu
D-niski komfort środków transportu
E-utrudniony przewóz rzeczy (np. nieporęczny bądź zbyt ciężki bagaż)
F-brak lub zbyt skromna siatka połączeń publicznego transportu zbiorowego na obszarze wędrówek
$\mathrm{G}$ - własny środek transportu zapewnia większą swobodę przemieszczania się
$\mathrm{H}$-zbyta duża liczba przesiadek po drodze

Ryc. 5. Przyczyny niewykorzystania transportu zbiorowego w dojeździe w góry Reasons for not using public transport in travelling to the mountains

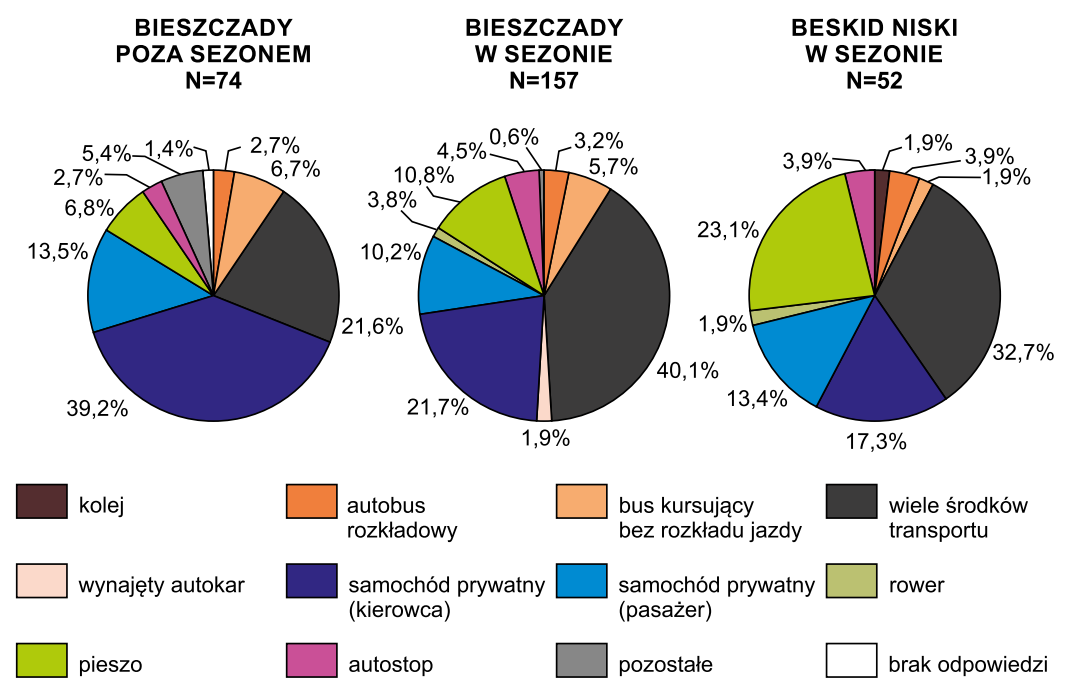

Ryc. 6. Środki transportu wykorzystywane w przejazdach w górach

Means of transport used to move around within the mountains

respondentów jako środek przemieszczania się. Nie jest to zaskakujące, gdyż w czerwcu brak jest sezonowych połączeń autobusowych, a busy kursujące bez rozkładu są znacznie mniej liczne, zwłaszcza po typowych godzinach zejścia ze szlaku. Bardziej złożona sytuacja 
panuje w Bieszczadach w wakacje. Oferta transportu zbiorowego w wakacje ulega tu znaczącej poprawie. Znacząco spada udział wykorzystania prywatnego samochodu oraz wzrasta udział respondentów korzystających z transportu zbiorowego (z 27\% do 40\%) (ryc. 6). Przy czym mamy tu na myśli także osoby deklarujące wykorzystywanie różnych form przemieszczania się w trakcie jednego pobytu. Beskid Niski posiada zupełnie inną specyfikę - blisko $1 \frac{1}{4}$ turystów przemieszcza się tu wyłącznie pieszo, do tego dochodzi pewna grupa wykorzystująca kombinacje środków przemieszczania się. Co zaskakuje, w obu pasmach bardzo mała grupa osób korzystała z niegdyś bardzo popularnego autostopu, będącego formą przyjaznego środowisko car-poolingu.

Nawet przy tak małej ankietowanej grupie w ocenie respondentów widać (ryc. 7), że pomimo wspomnianych wyżej mankamentów, wakacyjny transport zbiorowy w Bieszczadach jest zdecydowanie lepiej dopasowany do potrzeb turystów niż poza tym sezonem. Biorąc pod uwagę jednak skalę ocen dostatecznych można podejrzewać, że ta sytuacja mimo wszystko jest daleka od idealnej. Zaskakuje natomiast bardzo słaba ocena jakości transportu zbiorowego w Beskidzie Niskim, pomimo że jest ona (zwłaszcza wyrażona czę-

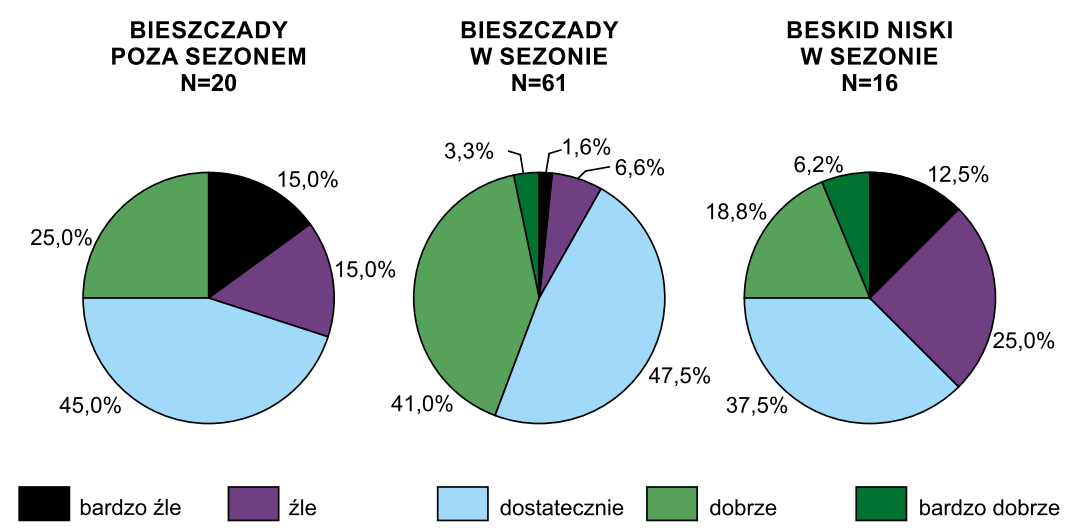

Ryc. 7. Ocena jakości publicznego transportu zbiorowego w przejazdach w górach Assessment of the quality of public transport in movement around the mountains

stotliwością kursów, przede wszystkim we wschodniej części pasma) znacznie lepsza niż na obszarze Bieszczad.

Wśród odpowiedzi respondentów pytanych o przyczyny niekorzystania z transportu zbiorowego w trakcie pobytu w górach (ryc. 8), podobnie jak w przypadku dojazdu w góry, dominowała elastyczność własnego samochodu. Ale nie ma to charakteru aż tak dominującego. Z punktu widzenia niniejszego badania jednak bardziej intersujące są inne czynniki. Niewątpliwie najuważniejszym z nich jest zbyt niska częstotliwość kursowania transportu zbiorowego. Nie jest to zaskakujące zwłaszcza w przypadku okresu przedwakacyjnego, gdy transport rozkładowy prawie nie istnieje, a pozarozkładowy ma częstotliwość zależną od wypełniania się busów, bądź też skłonności ich pasażerów do zapłacenia większej opłaty za szybsze ruszenie z przystanku początkowego. Jeśli odniesiemy liczbę odpowiedzi do liczby respondentów niekorzystających z transportu publicznego, to niska częstotliwość kursów w wakacje była w Bieszczadach głównym problemem dla 33\% 


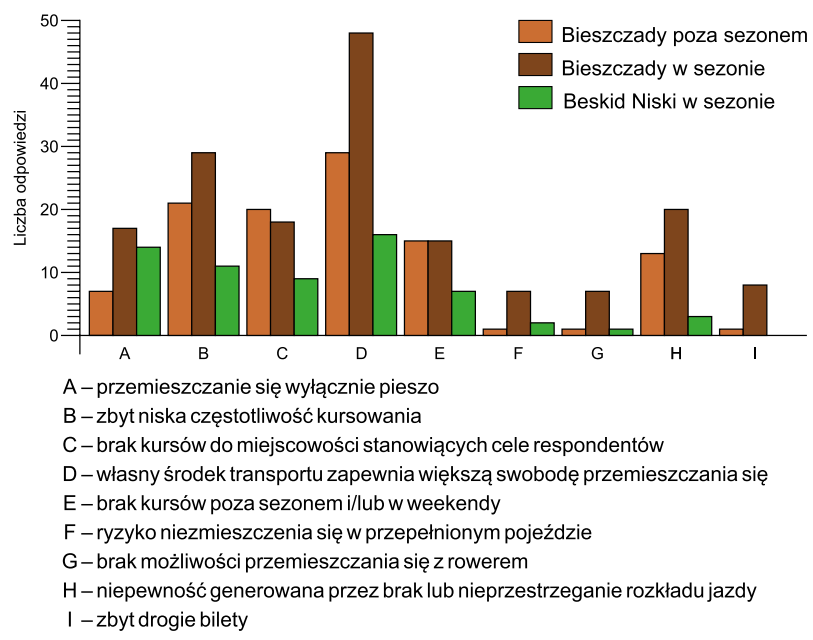

Ryc. 8. Przyczyny niewykorzystania transportu zbiorowego w przejazdach w górach Reasons for not using public transport in movement around the mountains

badanych, a w czerwcu aż 43\% badanych wskazywało na ten czynnik. Dla porównania w Beskidzie Niskim, gdzie dominuje sieć połączeń rozkładowych, na ten czynnik jako zniechęcający wskazywało $31 \%$ osób. W przypadku Bieszczad niewątpliwie pewien wpływ na takie postrzeganie częstotliwości wakacyjnej autobusów ma to, że kursują one bez rozkładu, trudno więc z góry zaplanować przejazd. Niezrozumiałe też jest to, że autobusy liniowe nakierowane są przede wszystkim na zapewnienie łączności miejscowości górskich takich Ustrzyki Górne, Wetlina, Cisna z Sanokiem. Poczynione wyrywkowo obserwacje wskazują na to, że największym obłożeniem te kursy cieszą na odcinku pomiędzy Ustrzykami Górnym a Cisną. Ponadto nie znajduje żadnego uzasadnienia wykonywanie większości tych kursów tylko dni robocze. Sytuacja latem jest o tyle lepsza, że między godzinami 8 a 18 busy bez rozkładu kursują niezależnie od ich wypełnienia. Ale rodzi to w punktach pośrednich ryzyko pozostania na przystanku. I faktycznie dla pewnej grupy respondentów spędzających wakacje w Bieszczadach był jeden z czynników zniechęcających do korzystania z transportu zbiorowego (przed sezonem oraz w Beskidzie Niskim miał on marginalne znaczenie). Ważnym elementem zniechęcającym do korzystania z transportu zbiorowego był jego całkowity brak w wielu miejscowościach, zwłaszcza zlokalizowanych poza główną osią komunikacyjną Cisna-Ustrzyki Górne. Do korzystania zniechęcał też brak kursów wieczorami (w Bieszczadach nawet w szczycie sezonu wakacyjnego busy przestają kursować około 18.00). Z tym wiąże się wspomniana niepewność generowana przez brak rozkładów jazdy lub ich nieprzestrzeganie. Natomiast ciekawy wniosek może dotyczyć aspektu ekonomicznego. O ile w Bieszczadach przed wakacjami i w Beskidzie Niskim latem on zbytnio się nie wyróżniał, to jednak latem opłaty za przejazd uzależnione od wypełnienia pojazdu poza godzinami szczytu stanowią dla turystów pewien problem. 


\section{Czy wykorzystanie samochodu przez turystów może przestać być koniecznością?}

Odpowiedź na powyżej postawione pytanie może być oczywiście pozytywna. Jednak należy podjąć działania, które sprawią, że publiczny transport zbiorowy znowu się stanie atrakcyjny dla turystów. Dlatego w trakcie badania wykonanego przez autorów w 2019 r. zadano respondentom pytania, na które odpowiedzi umożliwiły próbę wypracowania rekomendacji sprzyjających wprowadzeniu modelu zrównoważonego transportu na obszarze Beskidu Niskiego i Bieszczadów.

Dogodny dojazd transportem publicznym z miejsca zamieszkania jest warunkiem koniecznym, aby turyści w dojeździe w góry zrezygnowali z samochodu (ryc. 9). Oczekują oni zarówno w miarę bezpośrednich połączeń, jak również bardziej dopasowanego do ich potrzeb rozkładu jazdy (np. przyjazd rano, by maksymalnie wykorzystać posiadany czas na wędrówki). Biorąc pod uwagę konieczność przesiadek pożądana jest też większa częstotliwość połączeń, a także skrócenie długości przejazdu - szczególnie wskazane byłoby to w przypadku transportu kolejowego, który charakteryzuje się na beskidzkim odcinku zbyt niskim prędkościami. Natomiast w dalekobieżnym transporcie autobusowym jedynie miejscowości obsługiwane przez niebylecką firmę Neobus mogą liczyć na konkurencyjne względem motoryzacji indywidualnej czasy przejazdu. Transport publiczny też nie jest atrakcyjny w przewozie sprzętu sportowego. Jest to poważna wada, zwłaszcza że Beskid Niski stanowi dogodny teren dla rozwoju turystyki rowerowej, a jej połączenie z transportem publicznym idealnie wpisywałoby się w paradygmat turystyki zrównoważonej.

Dla polityki zrównoważonego rozwoju jednak ważniejsze jest ograniczenie wpływu motoryzacji indywidualnej w miejscu uprawiania turystyki. O ile w przypadku dojazdu

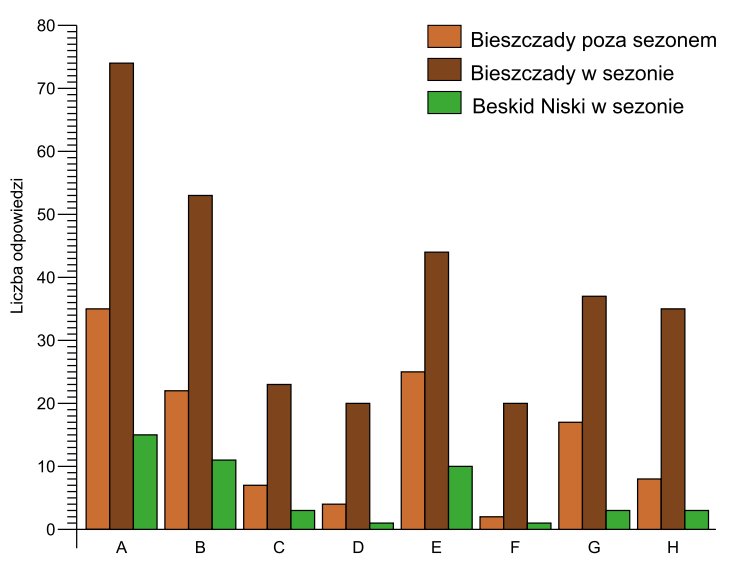

\footnotetext{
A -stworzenie dogodnych połączeń z miejsca zamieszkania respondenta do miejscowości turystycznych B -stworzenie bardziej dopasowanego do potrzeb turystów rozkładu jazdy C-obniżenie cen biletów

D-wymiana pojazdów na bardziej komfortowe

E-zwiększenie częstotliwości kursów

F-wprowadzenie promocji na zakup biletów

G-skrócenie czasu przejazdu

$\mathrm{H}$-umożliwienie swobodnego i niezawodnego przewozu większego sprzętu sportowego
}

Ryc. 9. Czynniki mogące zachęcić turystów do rezygnacji z motoryzacji indywidualnej w przy dojeździe w góry Factors capable of encouraging tourists to give up individual motorisation in travelling into the mountains 
w góry można dopuścić przemieszczanie się przez turystów samochodem, to na ich terenie pożądany byłby całkowity priorytet rozkładowego transportu publicznego. W Bieszczadach, których najcenniejsze przyrodniczo fragmenty stanowią obszar parku narodowego, powinno się dążyć do jak najmniejszego oddziaływania transportu na środowisko naturalne. Tymczasem tylko zapewnienie wyczerpującej siatki połączeń obejmującej łącznie miejsca noclegów i punkty wyjścia na szlaki oraz wysoka częstotliwość kursów autobusów są w stanie skłonić turystów do porzucenia samochodów i przesiadki na publiczny transport zbiorowy (ryc. 10). Ponadto powinna być zapewniona ciągłość kursowania nie tylko godzinach największego ruchu, ale także do późnego wieczora. O ile w sezonie wakacyjnym tego typu połączenia miałyby szanse samofinansować się, to jednak wskazane byłoby ich utrzymywanie także od maja do połowy października, tak by zachęcać turystów do przyjazdów także poza głównym sezonem turystycznym. Powinno temu towarzyszyć ograniczenie możliwości parkowania i przemieszczania się samochodami prywatnymi po drogach prowadzących przez obszar Bieszczadzkiego Parku Narodowego. Dofinansowany ze środków transport publiczny powinien też gwarantować lepszy komfort przejazdu niż wtórnie dostosowywane do przewozu samochody dostawcze i van.

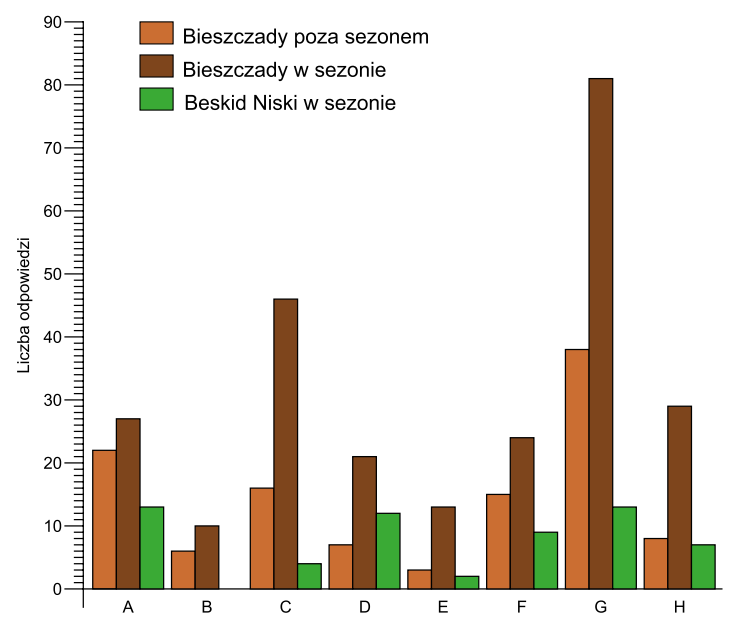
A-brak takiego środka transportu obsługującego docelową miejscowość B-zbyt wysokie ceny biletów
C-niekonkurecyjny (zbyt długi) czas dojazdu
D- niski komfort środków transportu
E-utrudniony przewóz rzeczy (np. nieporęczny bądź zbyt ciężki bagaż)
F-brak lub zbyt skromna siatka połączeń publicznego transportu zbiorowego na obszarze wędrówek
$\mathrm{G}$-własny środek transportu zapewnia większą swobodę przemieszczania się
$\mathrm{H}$-zbyta duża liczba przesiadek po drodze

Ryc. 10. Czynniki mogące zachęcić turystów do rezygnacji z motoryzacji indywidualnej w przejazdach w trakcie pobytu w górach

Factors capable of encouraging tourists to give up individual motorisation during a stay in the mountains

\section{Dyskusja}

Rezultaty badań ankietowych sugerują, że możemy mieć do czynienia ze zjawiskiem motoryzacji wymuszonej w turystyce. Termin ten można wywieść z pojęcia motoryzacja 
wymuszona (forced car ownership), które jako pierwszy zastosował Banister (1994) w odniesieniu do terenów wiejskich dla sytuacji, w której rodziny o niskich dochodach zostają przymuszone niejako do zakupu i użytkowania samochodu, ponieważ nie są dla nich dostępne inne opcje transportu. W warunkach australijskich (Gleeson i Randolph, 2002) dla tego samego zjawiska stosuje się termin ubóstwo transportowe (transport poverty) czyli sytuacja, w której gospodarstwa domowe muszą ponosić większe koszty transportu niż są w stanie. W przypadku Beskidu Niskiego, a zwłaszcza Bieszczad, możemy mówić ubogiej ofercie transportowej, która nawet w okresie wakacyjnym prowadzi do tego, że turyści są zmuszeni do wykorzystywania prywatnych samochodów zarówno w drodze w góry, jak również w trakcie przemieszczania się po nich.

Analiza zrównoważonego transportu dla rozwoju obszarów turystycznych powinna uwzględniać kwestie, o których pisał Więckowski (2021): sieci infrastruktury, organizacja, planowanie oraz promocja.

Sieć infrastruktury, za którą należy uważać infrastrukturę pozwalającą na przemieszczanie się, w tym drogi, linie kolejowe itd. często jest niezależna od destynacji turystycznej, ale może być kształtowana pod kątem potrzeb turystycznych w wyniku nadrzędnej polityki (np. państwa, ale też regionu). Plany tworzenia nowej infrastruktury oraz jej wykonanie trwają wiele lat i często są spóźnione względem potrzeb (Więckowski, 2021). Ze względu na układ odziedziczonej po zaborcy sieci kolejowej o jakiejkolwiek poprawie warunków przejazdu można mówić jedynie w aspekcie dojazdu do miejscowości zlokalizowanych na przedpolu badanego obszaru. Koniecznym wydaje się doprowadzenie linii kolejowych w regionie do stanu, w którym czas przejazdu pociągu będzie w stanie konkurować z motoryzacją indywidualną. Także poprawa jakości sieci drogowej, zwłaszcza budowa dróg ekspresowych, wpłynie zapewne pozytywnie na atrakcyjność dojazdu w omawiane pasma górskie. W przypadku lokalnej infrastruktury drogowej nie stanowi ona większej bariery. Niestety bez podjęcia zmian na poziomie organizacyjnym inwestycje w infrastrukturę liniową będą miały słaby wpływ na wzrost udziału transportu zrównoważonego na przedmiotowym obszarze.

Organizacja. Użytkownicy potencjalnie konkurują o transport w kategoriach dostępu do przewoźników publicznych, przestrzeni drogowej, miejsc parkingowych, ścieżek rowerowych i pieszych. Elementy te, a także połączenia i możliwości środków transportu można dostosować do istniejących potrzeb. Należy pamiętać, że mogą one bazować na istniejącej infrastrukturze, oraz możliwościach środków transportu. Zmiany środków transportu oraz regulacji wpływają zarówno na dostępność, jak też na jakość transportu i mogą być kształtowane przez władze destynacji turystycznych. W Polsce w przypadku transportu autobusowego dominuje niestety rynkowy model funkcjonowania, w którym samorządy tylko formalnie pełnią rolę organizatora tej formy publicznego transportu zbiorowego. Na badanym obszarze jedynie samorząd powiatu jasielskiego przyjął na siebie rolę aktywnego zarządcy sieci połączeń autobusowych. Pewne elementy woli wpływania na sytuację obserwowane są też w powiecie gorlickim. Nie zmienia to jednak faktu, że jeśli nawet władze powiatowe w jakiś sposób interweniują na rynku, to przede wszystkim w celu zapewnienia dojazdu do szkół czy miejsc pracy, a nie z punktu widzenia turystów. Na przeciwległym biegunie jest np. powiat leski, którego przedstawiciel w trakcie rozmowy przeprowadzonej jesienią 2019 r. uznał, że doskonale sprawdzają się na jego terenie pojazdy kursujące bez rozkładu, a często bez wydawanych biletów. Bez zmiany sposo- 
bu myślenia samorządowców o organizacji transportu publicznego trudno będzie mówić o zrównoważonej turystyce.

Planowanie na różnych poziomach, od lokalnego, poprzez regionalny po krajowy, może być źródłem zmian, propozycji oraz działań na rzecz poprawy dostępności oraz dostosowania możliwości transportowych do potrzeb turystycznych (i odwrotnie) (Saarinen, 2014; Więckowski, 2021). Ma to szczególne znaczenie dla destynacji turystycznych. Władze regionu (województwa podkarpackiego), gminy czy miasta mogą kształtować zarówno politykę transportową, jak też wpływać na przekształcenia strukturalne: rodzajów transportu, ich energochłonności, emisji szkodliwych substancji i kierunków funkcjonowania. Może to służyć poprawie funkcjonowania transportu, łączenia potencjałów (lokalnego i turystycznego), kształtowania transportu zrównoważonego. Bazując na obserwacjach oraz przeprowadzonych rozmowach można odnieść wrażenie, że nadal brakuje szerszego spojrzenia samorządowców na kwestie zrównoważonego rozwoju i związanego z nim planowania (por. Ćwik i Hrehorowicz-Gaber, 2021). Dopóki nie zostaną wdrożone właściwe schematy organizacji transportu zbiorowego na badanym obszarze, dopóty nie będzie podstaw planowania służącego zwiększeniu skali wdrażania rozwoju zrównoważonego (np. wyprowadzenia ruchu samochodów osobowych i parkowania z obszaru Bieszczadzkiego Parku Narodowego). Brak dbałości o dobre planowanie może w konsekwencji prowadzić również do wielu konfliktów przestrzennych (por. Bednarek-Szczepańska et al., 2010).

Promocja jako element szerszego marketingu może być wykorzystana do celowego i świadomego kształtowania podaży i popytu, zmian środków transportu i większego nacisku na konieczność i możliwość korzystania z transportu zbiorowego w turystyce. Transport jednak rzadko jest przedmiotem reklam i jako taki powinien stać się elementem przemyślanych strategii marketingowych w destynacjach turystycznych (Więckowski, 2021). Promocja publicznego transportu zbiorowego w obecnej sytuacji jest daleka od ideału, zwłaszcza gdy gros obsługi transportowej w Bieszczadach stanowią busy poruszające się bez rozkładu jazdy, a rola rozkładowych przewoźników autobusowych jest marginalna. Znacznie lepsza sytuacja panuje w Beskidzie Niskim, gdzie funkcjonują wyłącznie przewoźnicy rozkładowi, jednak cieniem kładzie się tu brak uregulowań ogólnokrajowych w dziedzinie publikacji rozkładów jazdy w jednym miejscu - skrajnym przykładem są firmy, których rozkłady można znaleźć jedynie na przystankach autobusowych. Warto więc byłoby wdrożyć narzędzia, które przynajmniej w skali regionalnej umożliwiałyby pełne planowanie podróżowania w jednym miejscu. Inaczej trudno będzie osiągnąć efekt, w którym publiczny transport zbiorowy będzie bardziej atrakcyjny od przejazdów własnym autem.

Nawet w przypadku znacznego usprawnienia systemu transportu zbiorowego i wykorzystania bodźców ekonomicznych do transportu przyjaznego środowisku, wzrost udziału turystów korzystających z niego będzie trudny do osiągnięcia, gdyż trend w tym zakresie jest zupełnie odwrotny. Preferują oni transport indywidualny. Już obecnie wzrost użytkowania transportu prywatnego spowodował korki i doprowadził do przeładowania parkingów. Destynacje nie były przygotowane na takie zmiany. Inwestycje, polityka i promocja w transporcie publicznym powinny być zgodne z polityką zrównoważonego rozwoju (Michniak i Więckowski, 2021). Ponadto, w dalszy proces planowania i proponowania nowych rozwiązań powinny być włączone społeczeństwa lokalne, z uwzględnieniem zasad planowania partycypacyjnego (Zawilińska i Szpara 2016; Bednarek-Szczepańska, 2020). 


\section{Podsumowanie}

Peryferyjność Beskidu Niskiego i Bieszczad względem większości kraju sprawia, że w dojeździe w te pasma żaden środek publicznego transportu zbiorowego nie jest w stanie konkurować czasowo z prywatnym samochodem. Jednak jak wskakują wyniki przeprowadzonego pilotażu istnieje stosunkowo liczna grupa turystów, którzy zdecydowaliby się na dojazd pociągiem czy autobusem, gdyby nie zbyt wydłużony czas przejazdu, wiążący się nierzadko z uciążliwymi przesiadkami. Dojazd prywatnym autem niewątpliwie jest czynnikiem zachęcającym do wykorzystania go także na obszarze, na którym uprawia się turystykę, szczególnie przez osoby, które cenią sobie pewną swobodę i niezależność jaką daje ten pojazd. Z drugiej jednak strony z przeprowadzonego badania można wyprowadzić wnioski, że część turystów, gdyby oferta ptz była lepsza, skorzystałby z jego usług. Zwłaszcza, że układ szlaków w obydwu pasmach wręcz nie sprzyja wykorzystaniu samochodu. Niestety, z odpowiedzi respondentów dość jasno wynika, że siatka połączeń omijająca główną oś Cisna-Ustrzyki Górne, zbyt niska częstotliwość kursów oraz ich nieprzewidywalność poza godzinami największego ruchu sprawiają, że podejmują oni także decyzje o przemieszczaniu się autem na miejscu, choć często jest to nieekonomiczne i nieekologiczne oraz generuje zbędą emisję spalin poprzez konieczność rozmieszczenia samochodów na początku i na końcu trasy.

Zainteresowanie turystów Bieszczadami, a także Beskidem Niskim w ostatnich 30 latach znacząco wzrosło. Niestety w parze z tym nie szedł rozwój oferty transportu zbiorowego. Do wielu górskich miejscowości przestały docierać rozkładowe autobusy i busy, a do innych nadal docierają, ale rzadziej albo tylko w dni nauki szkolnej, co przekreśla ich wykorzystanie przez turystów. Nawet gdyby chcieli oni porzucić samochody i przemieszczać się sposobami bardziej zgodnymi z ideą zrównoważonego rozwoju, nie mają na to szans. Skala tych negatywnych procesów jest szczególnie dostrzegalna na obszarach najsłabiej zaludnionych, w tym na trudniej dostępnych obszarach górskich (Ciechański, 2020).

Tymczasem samorządy, pomimo ustawowego obowiązku, nie podejmują się organizacji transportu publicznego na terenie podległych jednostek podziału administracyjnego. Rezultatem tego jest rosnąca wśród turystów motoryzacja wymuszona prowadząca do wzrostu antropopresji i wzrostu emisji gazów cieplarnianych. Warto zwrócić uwagę na fakt, że w Bieszczadach problem ten nie dotyczy tylko motoryzacji indywidualnej, ale także "szarej strefy” - przewoźników jeżdżących bez rozkładu i niewydających biletów. Prawdopodobnie problem ten by nie występował, gdyby na przedmiotowym obszarze funkcjonował sprawny publiczny transport zbiorowy, organizowany przez samorząd województwa podkarpackiego. Taki model sprawiłby, że sezon turystyczny mógłby trwać dłużej, a w październiku nie byłoby widoku przepełnionych parkingów na Przełęczy Wyżniej czy Wyżniańskiej. Wydłużenie sezonu turystycznego również mogłoby mieć korzystny wpływ na środowisko przyrodnicze. Biorąc pod uwagę, jaka jest świadomość części osób odpowiedzialnych za organizację publicznego transportu zbiorowego na przedmiotowym terenie (w mniemaniu części z nich, skoro funkcjonują busy z „szarej strefy” to nie ma ze strony samorządu potrzeby interwencji), niestety nie można oczekiwać szybkiej poprawy opisywanej niekorzystnej sytuacji.

Ryciny i tabele, pod którymi nie zamieszczono źródła, są opracowaniem własnym autorów artykułu. 


\section{Piśmiennictwo}

Bagińska, J. (2007). Kilka uwag na temat linii pasażerskich w Polsce w latach 1989-2006. Prace Komisji Geografii Komunikacji PTG, 14, 157-164.

Banister, D. (1994). Equity and acceptability in internalising the social costs of transport. W: Internalising the social costs of transport (s. 153-175). EMCT.

Bednarek-Szczepańska, M. (2020). Współczesne podejścia do uczestnictwa społeczności lokalnej w planowaniu przestrzeni w literaturze naukowej, Przeglqd Geograficzny, 92(4), 543-567. https://doi.org/10.7163/PrzG.2020.4.5

Bednarek-Szczepańska, M., Więckowski, M., \& Komornicki, T. (2010). Konflikty przestrzenne w wybranych gminach. W: P. Śleszyński, J. Solon, Prace planistyczne a konflikty przestrzenne w gminach (s. 90-120). Studia KPZK, 130. Warszawa: Komitet Przestrzennego Zagospodarowania Kraju PAN.

Beim, M., Błażeczek, A., Dąbrowska, A., Dębiak, P., \& Olczyk, A. (2019). Badania dostępności publicznego transportu zbiorowego w podregionie pilskim. Prace Komisji Geografii Komunikacji Polskiego Towarzystwa Geograficznego, 22(4), 95-118. https://doi.org/10.4467/2543859XPKG.19.021.11542

Bissaga, T. (1938). Geografia kolejowa Polski z uwzględnieniem stosunków gospodarczo-komunikacyjnych. Warszawa: Wydawnictwa Techniczne Ministerstwa Komunikacji.

Black, W.R. (2003). Transportation: A Geographical Analysis. London: Guilford Press.

Buza, M., \& Turnock, D. (2004). A research note: planning for the Carpathians, Geojournal, 68, 135-142. https://doi.org/10.1023/B: GEJO.0000033589.04305.fe

Cardenas Tabares, F. (1998). Producto Turistico: Aplicacao de la Estadistica y del Muestreo Para su Diseno (2nd ed.). Mexico City: Trillas.

Chodkowska-Miszczuk, J. (2006). Zmiany na rynku przewozów samochodowym transportem zbiorowym w wybranych miastach Polski, Przegląd Geograficzny, 78(2), 261-284.

Ciechański, A. (2013). Rozwój i regres sieci kolei przemysłowych w Polsce w latach 1881-2010. Prace Geograficzne, 243. Warszawa: Instytut Geografii i Przestrzennego Zagospodarowania PAN.

Ciechański, A. (2019). Wyzwania w badaniach sieci pozamiejskiego transportu autobusowego na przykładzie powiatów Beskidu Niskiego i Bieszczad. Prace Komisji Geografii Komunikacji PTG, 22(2), 74-81. https://doi.org/10.4467/2543859XPKG.19.012.11152

Ciechański, A. (2020). Zmiany w sieci transportu publicznego na obszarach Beskidu Niskiego i Bieszczad 1990-2019 i ich konsekwencje. Studia Regionalne i Lokalne, 81(3), 49-77.

https://doi.org/10.7366/1509499538103

Ćwik, A., \& Hrehorowicz-Gaber, H. (2021), Causes and effects of spatial chaos in the Polish Carpathians - a difficult way to sustainable development. European Countryside, 13(1), 153-174. https://doi.org/10.2478/euco-2021-0009

Dej, M. (2010). Transport publiczny w wiejskich obszarach peryferyjnych Polski i jego dostosowanie do potrzeb lokalnych rynków pracy. Prace Geograficzne, 124, 111-130.

Faracik, R., Kurek, W., Mika, M., \& Pawlusiński, R. (2009). Turystyka w Karpatach Polskich w świetle współczesnych kierunków rozwoju. W: B. Domański, W. Kurek (red.), Gospodarka i przestrzeń (s. 77-98). Kraków: Uniwersytet Jagielloński.

Gleeson, B., \& Randolph, B. (2002). Social disadvantage and planning in the Sydney context. Urban Policy and Research, 20(1), 101-107. https://doi.org/10.1080/08111140220131636

Green Paper on the Impact of Transport on the Environment. A Community Strategy for 'Sustainable Mobility'. (1992). Brussels: European Commission.

Groch, J., \& Kurek, W. (1995). Turystyka. W: J. Warszyńska (red.), Karpaty Polskie. Przyroda, człowiek i jego działalność (s. 265-300). Kraków: Uniwersytet Jagielloński. 
Guiver, J., Lumsdon, L., Weston, R., \& Ferguson, M. (2007). Do buses help meet tourism objectives? The contribution and potential of scheduled buses in rural destination areas, Transport Policy, 14(4), 275-282. https://doi.org/10.1016/j.tranpol.2007.02.006

Guzik, R., \& Kołoś, A. (2015). Dostępność komunikacyjna. W: R. Guzik, A. Kołoś (red.), Relacje funkcjonalno-przestrzenne między ośrodkami miejskimi i ich otoczeniem w województwie pomorskim, Pomorskie Studia Regionalne (s. 217-268). Gdańsk: Urząd Marszałkowski Województwa Pomorskiego.

Guzik, R., Kołoś, A., Gwosdz, K., Biernacki, W., Działek, J., Kocaj, A., Panecka-Niepsuj, M., \& Wiedermann, K. (2016). Dostępność, relacje i powiqzania przestrzenne w Miejskim Obszarze Funkcjonalnym Olsztyna, Kraków: Uniwersytet Jagielloński.

Hall, D.R. (1999). Conceptualising tourism transport: inequality and externality issues. Journal of Transport Geography, 7, 181-188. https://doi.org/10.1016/S0966-6923 (99)00001-0

Himanena, V., Lee-Gosselinb, M., Perrels, A. (2005). Sustainability and the interactions between external effects of transport. Journal of Transport Geography, 13, 23-28. https://doi.org/10.1016/j.jtrangeo.2004.11.006

Holden, E. (2007). Achieving Sustainable Mobility: Everyday and Leisure-Time Travel in the EU. Aldershot: Ashgate.

Imhof, R., Vogel, M., Ruiz, G. (2009). Mobility and protected areas in the Alps. Ecomont, 1(1), 57-62. https://doi.org/10.1553/eco.mont1s57

Jabs, Z.J., \& Affek, A.N. (2019). Dostępność rolnicza Beskidów, Przegląd Geograficzny, 91(2), 97-111. https://doi.org/10.7163/PrzG.2019.2.6

Kołodziejczyk, K. (2017). Zmiany dostępności komunikacyjnej ziemi kłodzkiej wobec jej funkcji turystycznych - wybrane zagadnienia. Transport Miejski i Regionalny, 4, 18-25.

Kołodziejczyk, K. (2020). Cross-border public transport between Poland and Czechia and the development of the tourism functions of the region, Geographia Polonica, 93, 2, 261-285. https://doi.org/10.7163/GPol.0173

Komusiński, S. (2010). Przekształcenia przestrzenne sieci pasażerskiego transportu kolejowego w Polsce w latach 1988-2008. Kraków: Uniwersytet Jagielloński (maszynopis pracy doktorskiej).

Kozanecka, M. (1980). Tendencje rozwojowe komunikacji autobusowej w Polsce: studium geograficzno-ekonomiczne, Kraków: Wydawnictwo Naukowe Wyższej Szkoły Pedagogicznej.

Koziarski, S. (1985). Elektryfikacja sieci kolejowej w Polsce. Czasopismo Geograficzne, 56(1), 31-44.

Koziarski, S. (1989). Sieć kolejowa w aglomeracjach miejsko-przemysłowych makroregionu południowego. Opole: Instytut Śląski.

Koziarski, S. (1990). Rozwój sieci kolejowej na Ślq̨sku. Opole: Instytut Śląski.

Koziarski, S. (1993a). Sieć kolejowa Polski w latach 1842-1918. Opole: Instytut Śląski.

Koziarski, S. (1993b). Sieć kolejowa Polski w latach 1918-1992. Opole: Instytut Śląski.

Kretowicz, P. (2010). Komunikacja lokalna w obszarach peryferyjnych województwa małopolskiego w dobie przemian rynku przewozów autobusowych. Prace Geograficzne, 124, 131-146.

Le-Klähn D.-T., \& Gerike, R., Hall, C.M. (2014). Visitor users vs. non-users of public transport: The case of Munich, Germany. Journal of Destination Marketing \& Management, 3, 152-161. https://doi.org/10.1016/j.jdmm.2013.12.005

Le-Klähn, D.-T. \& Hall, C.M. (2015). Tourist use of public transport at destinations - a review. Current Issues in Tourism, 18(8), 785-803. https://doi.org/10.1080/13683500.2014.948812

Lijewski, T. (1959). Rozwój sieci kolejowej Polski. Dokumentacja Geograficzna, 5. Warszawa: Instytut Geografii PAN. 
Lijewski, T. (1962). Geografia komunikacyjna województwa białostockiego. Dokumentacja Geograficzna, 2. Warszawa: Instytut Geografii PAN.

Lijewski, T., \& Koziarski, S. (1995). Rozwój sieci kolejowej w Polsce. Warszawa: Kolejowa Oficyna Wydawnicza.

Lijewski, T., Lenk, J., \& Piotrowska, H. (1967). Rozwój komunikacji kolejowej i autobusowej w Polsce w okresie 1946-1965. Dokumentacja Geograficzna, 6. Warszawa: Instytut Geografii PAN.

Lumsdon, L. (2006). Factors affecting the design of tourism bus services. Annals of Tourism Research, 33(3), 748-766. https://doi.org/10.1016/j.annals.2006.03.019

Michniak, D., \& Więckowski, M. (2021). Changes of Transport in Cross-Border Tourist Regions in the Polish-Slovak Borderland: An (Un) Sustainable Development? W: L. Zamparini (red.) Sustainable Transport and Tourism Destinations. Transport and Sustainability, 13 (s. 11-25). Bingley: Emerald Publishing Limited. https://doi.org/10.1108/S2044-994120210000013004

Michniak, D., Więckowski, M., Stępniak, M., \& Rosik, P. (2015). The impact of selected planned motorways and expressways on the potential accessibility of the Polish-Slovak borderland with respect to tourism development. Moravian Geographical Reports, 1, 13-20.

https://doi.org/10.1515/mgr-2015-0002

Prideaux, B. (2000). The role of transport in destination development. Tourism Management, 21, 53-63. https://doi.org/10.1016/S0261-5177 (99)00079-5

Ptaszycka-Jackowska, D. \& Baranowska-Janota, M. (2003). Tourism within the Polish and Slovak Transfrontier Region, Prace Geograficzne, 111, 44-60.

Richardson, B. (2005). Sustainable transport: analysis frameworks. Journal of Transport Geography, 13(1), 29-39. https://doi.org/10.1016/j.jtrangeo.2004.11.005

Rosik, P., Pomianowski, W., Goliszek, S., Stępniak, M., Kowalczyk, K., Guzik, R., Kołoś, A., \& Komornicki, T. (2017). Multimodalna dostępność transportem publicznym gmin w Polsce (MULTIMODACC). Prace Geograficzne, 258, Warszawa: Instytut Geografii i Przestrzennego Zagospodarowania PAN.

Saarinen, J., (2014). Critical Sustainability: Setting the Limits to Growth and Responsibility in Tourism. Sustainability, 6(1), 1-17. https://doi.org/10.3390/su6010001

Sorupia, E. (2005). Rethinking the role of transportation in tourism. Proceedings of the Eastern Asia Society for Transportation Studies, 5, 1767-1777.

Stawicki, M. (2014). Autobusowy transport zbiorowy w dojazdach do pracy do Warszawy z gmin woj. mazowieckiego. Logistyka, 4, 3720-3728.

Székely, V., \& Novotný, J. (2019). Spatial differences in public transport accessibility of district centres in the Prešov region, Slovakia. Prace Komisji Geografii Komunikacji PTG, 22(1), 31-43. https://doi.org/10.4467/2543859XPKG.19.003.10923

Taylor, Z. (2007). Rozwój i regres sieci kolejowej w Polsce. Monografie, 7. Warszawa: Instytut Geografii i Przestrzennego Zagospodarowania PAN.

Taylor, Z. (2018). Współdziałanie, rola i sposoby transportu w turystyce i rekreacji. Przeglqqd Geograficzny, 90(4), 531-555. https://doi.org/10.7163/PrzG.2018.4.1

United Nations Environment Programme (UNEP and UNWTO: Division of Technology, Industry and Economics). (2005). Making Tourism More Sustainable: A Guide for Policy Makers. Paris: UNEP. Warszyńska, J. (1985). Funkcja turystyczna Karpat Polskich. Folia Geographica, seria Geographica Oeconomica, 18, 79-104.

Więckowski, M. (2004). Przyrodnicze uwarunkowania kształtowania się polsko-słowackich więzi transgranicznych. Prace Geograficzne, 195. Warszawa: Instytut Geografii i Przestrzennego Zagospodarowania PAN. 
Więckowski, M. (2020). Natural heritage as a resource for tourism development in the Polish Carpathians, Geografický časopis, 72(3), 243-259. https://doi.org/10.31577/geogrcas.2020.72.3.12

Więckowski, M. (2021). Will the Consequences of Covid-19 Trigger a Redefining of the Role of Transport in the Development of Sustainable Tourism? Sustainability, 13(4), 1887. https://doi.org/10.3390/su13041887

Więckowski, M., Michniak, D., Bednarek-Szczepańska, M., Chrenka, B., Ira, V., Komornicki, T., Rosik, P., Stępniak, M., Szekely, V., Śleszyński, P., Świątek, D., \& Wiśniewski, R. (2012). Pogranicze polsko-słowackie. Dostępność transportowa a turystyka, Warszawa-Bratysława: IGiPZ PAN-GU SAV.

Więckowski, M. \& Saarinen, J. (2019). Tourism transitions, changes, and the creation of new spaces and places in Central-Eastern Europe. Geographia Polonica, 92(4), 369-377. https://doi.org/10.7163/GPol.0154

Wolański, M., Paprocki, W., Mazur, B., Soczówka, A., Jakubowski, B., Czubak, M., \& Pieróg, M. (2016). Publiczny transport zbiorowy poza miejskimi obszarami funkcjonalnymi. Warszawa: Oficyna Wydawnicza SGH.

Zawilińska, B. (2010). Możliwości rozwoju turystyki w parkach krajobrazowych Karpat Polskich w świetle idei zrównoważonego rozwoju. Monografie: Prace Doktorskie. Kraków: Uniwersytet Ekonomiczny w Krakowie.

Zawilińska, B., \& Szpara, K. (2016). Participative model of tourism development planning in a region of high natural value: a case study of The Polish Carpathians. Scientific Review of Physical Culture, 5(4), 242-253.

\section{Summary}

Transport is an integral part of tourism and the latter would not function without the development of the former. The issue of transport accessibility is of particular importance, when it comes to both reaching an area and the possibilities for moving around within it. A lack of convenient transport possibilities diminishes the tourist potential of a given area. Public transport is essential in naturally-valuable areas. Because of the massive development of tourism and its negative effects on the environment, sustainable development principles assume importance and questions arise regarding the limits of tourism's development. The aim of this paper was to answer a specific question of relevance to the above, i.e. does the regression of public transport in the naturally-valuable areas that are Poland's Low Beskid (Beskid Niski) and Bieszczady Mountains lead to unsustainable development?

The authors carried out a questionnaire survey and analysed changes in the public-transport network between 2019 and 1990. Questionnaires were addressed to tourists visiting these mountains and included questions on accessibility to these mountain regions in the first place, as well as the possibilities for moving around within them. A database of public-transport timetables (valid as of the beginning of 2019) was created to analyse connections on an average working day, as well as during the weekends or holidays that are of special importance from the point of view of tourists.

The survey results suggest that we may be dealing with the phenomenon of forced motorisation in tourism. In the case of the Low Beskids, and especially the Bieszczady Mountains, we can talk about a certain impoverishment of the offer regarding transport, 
with this ensuring - even during the holiday season - that tourists are forced to use private cars both on their way into the mountains and while travelling around within them.

The interest tourists show in the Low Beskids, and especially the Bieszczady Mountains, has increased very markedly over the last 30 years. Unfortunately, the development of the offer as regards public transport has not merely failed to match that, but has followed an opposing trend. Scheduled bus and minibus services have stopped reaching many mountain villages. While these still reached many destinations as of 2019, they did so less often, or were confined to school days, hence implying a basic unsuitability for use in tourism. The role of rail transport in the studied area is marginal. Overall, the results obtained mediate against any possibility of truly sustainable development of transport in the area under study.

Nevertheless, with a view to such a model for sustainable transport in the area studied being provided, the authors have sought to make certain recommendations. A favourable situation as regards this tourist region's accessibility by public transport from places of residence is of course a precondition for any decision-making choice when it comes to selecting modes of travel that potential or actual tourists are in a position to make. Furthermore, direct connections will be important conditioners of desirable decisions, as will be timetables better tailored to the particular needs of tourists. As regards the making of transfers, greater frequency of connections and shorter travel times are further favourable aspects. On the other hand, it is important that the impact of individual motorisation around tourist destinations (or whole regions) should be limited, with this achievable where overall priority is assigned to scheduled public transport (as inevitably enjoying partial support from regional authorities). 